\title{
Bank Competition and Firm Creation
}

Emilia Bonaccorsi di Patti and Giovanni

Dell'Ariccia 


\title{
IMF Working Paper
}

\author{
Research Department
}

\section{Bank Competition and Firm Creation}

\author{
Prepared by Emilia Bonaccorsi di Patti and Giovanni Dell'Ariccia* \\ Authorized for distribution by Eduardo Borensztein
}

February 2001

\begin{abstract}
The views expressed in this Working Paper are those of the author(s) and do not necessarily represent those of the IMF or IMF policy. Working Papers describe research in progress by the author(s) and are published to elicit comments and to further debate.
\end{abstract}

This paper investigates the empirical relationship between competition in the financial sector and the creation of firms in the non-financial sector. It finds that bank competition has an overall positive effect on firm creation. However, consistent with theories of banking arguing that competition may reduce the availability of credit to informationally opaque firms, it also finds that asymmetric information limits the overall positive effect of bank competition on firm creation. Indeed, bank competition is less favorable to the emergence of new firms in industrial sectors where informational asymmetries are more important, and in extreme cases has a negative effect.

JEL Classification Numbers:E51, G21

Keywords: Bank Competition, Asymmetric Information, Growth

Authors' E-Mail Address: bonaccorsidipatti.emilia@insedia.interbusiness.it gdellariccia@imf.org

\footnotetext{
"Emilia Bonaccorsi di Patti is at the Bank of Italy, this paper was in part written while she was visiting the IMF. We thank Allen Berger, Fabio Canova, Nicola Cetorelli, Daniel Covitz, Giorgio Gobbi, Robert Marquez, Fabio Panetta, Rafael Repullo, Jeromin Zettelmeyer, and seminar participants at the Bank of Italy, Universita' di Roma II, the Chicago Fed. Conference on Bank Structure, and the Wharton-CFS Conference on Bank Competition for their useful suggestions. All the errors are ours.
} 


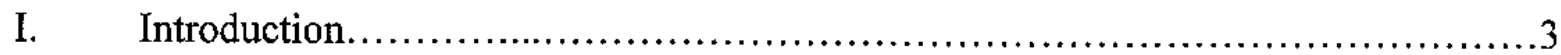

II. Theoretical Issues and Previous Empirical Literature ..................................

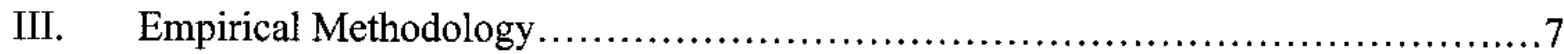

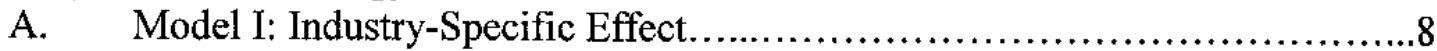

B. $\quad$ Model II: Economy-Wide Effect...........................................9

C. Measuring Credit Availability ........................................ 10

D. Measuring the Degree of Opaqueness..................................11

E. Measuring Bank Competition.........................................14

F. Data and Variable Description.........................................15

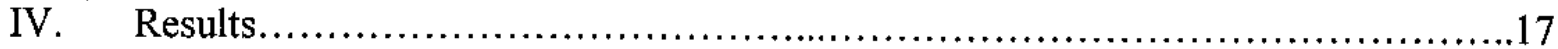

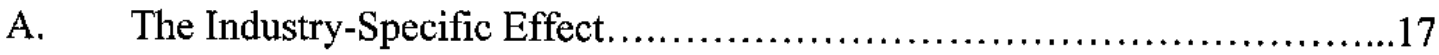

B. The Economy-Wide Effect...............................................

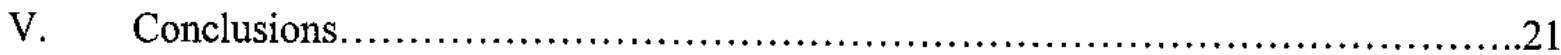

Tables:

1. Indicators of Asymmetric Information..................................22

2. Industry Ranking and Opaqueness Measures.............................23

3. Variable Definition and Descriptive Statistics..............................24

4-A. Bank Competition and Firm Birth Rate (ASYM) ..........................25

4-B. Bank Competition and Firm Birth Rate (ASYM for Young Firms).............26

5-A. Bank Competition and Firm Birth Rate (ASYM, Controlling for DEATH)...27

5-B. Bank Competition and Firm Birth Rate (ASYM, for Young Firms, Controlling for DEATH) ............................................ 28

6. Bank Competition and Firm Birth Rate (ASYM, Controlling for Start-up Cost).

7. Bank Competition and Firm Birth Rate (ASYM Instrumental Variables Estimation) ........................................................

8. Bank Competition and Firm Birth Rate (Robustness with all Indicators)......31

9. Bank Competition and Firm Birth Rate: Total Effect..........................32

Figure1. Derivative of BIRTH with respect to HERF, as a function of HERF...........33

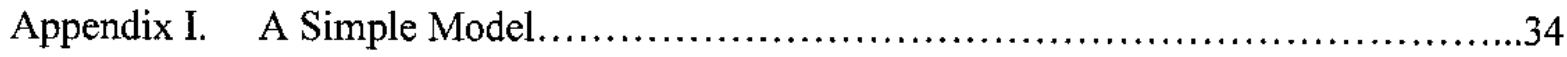

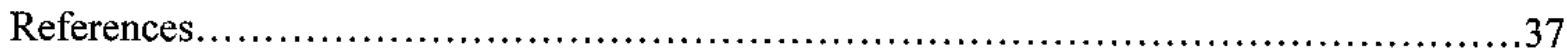




\section{INTRODUCTION}

Competition within the banking industry affects the supply of credit and has important consequences for borrowers depending on bank credit for their external financing. In particular, in countries where banks represent the main source of external capital for entrepreneurs starting brand new activities, the availability of bank credit has been identified as a precondition for the birth and the development of new firms, affecting through this channel employment and economic growth.

Traditional theories of industrial organization univocally predict a positive relationship between the degree of competition among banks and their supply of credit to non-financial firms. Other "information-based" theoretical contributions have challenged that view. These theories have argued that adverse selection, moral hazard, and hold-up problems increase with the degree of competition under asymmetric information. In such circumstances, some monopoly power in the banking industry may be beneficial to the availability of credit to non-financial firms. However, the related empirical literature has not yet incorporated these theoretical developments, continuing to base its estimations on traditional industrial organization models.

In the attempt to fill that gap, this paper introduces a new approach that explicitly includes information asymmetries in an empirical model of the effect of bank competition on credit availability.

One testable implication of information-based theories is that banks in a relatively more competitive environment will tend to provide relatively less credit to those industries where informational asymmetries are more severe. Consequently, we should find that measures of competition in the banking sector have a negative differential effect on measures of credit availability to firms in industries with increasing degrees of information asymmetries.

The empirical analysis in this paper focuses on the relationship between the rate of birth of non-financial firms in a sample of industries, as a measure of credit availability, and a variety of measures of the degree of competition in a set of local credit markets.

We employ two complementary empirical models. In our base estimation we focus exclusively on the differential effect. We regress the rate of birth of firms in each industry and each local credit market on an interaction term consisting of the product of a measure of bank competition in the local market and a measure of information asymmetries in the industry, on industry and market fixed effects, and other control variables. ${ }^{1}$ As described below, the coefficient of the interaction term times the measure of information asymmetry is an estimate of the differential effect of bank competition on the rate of birth of firms. In the second part of the paper, we attempt to estimate the economy-wide effect of bank competition on the rate of birth of

\footnotetext{
${ }^{1}$ This testing strategy follows in spirit the methodology that Rajan and Zingales (1998) use to identify the relationship between financial development and growth.
} 
firms by including the measure of bank competition directly in the regression and dropping the market fixed effects.

The analysis considers the rate of birth of firms as one specific aspect of credit availability because it is most likely that asymmetric information problems result in firms not being able to start rather than in restrictions on the quantity of credit that existing firms can get. Furthermore, because of their special characteristics (for example: the absence of previous credit history) new firms are ideal candidates to study the effects of banking competition in the presence of informationally opaque borrowers.

With regard to asymmetric information, this paper focuses on the degree of "opaqueness", meaning the inability for external lenders to evaluate entrepreneurial activities, as the defining characteristic of firms vis-à-vis the banking system. We assume that, for technological reasons, banks find it more difficult to evaluate the credit-worthiness of firms in particular industries. We argue that such reasons get translated into specific characteristics of balance sheets (the proportion of physical capital and other fixed assets), and into the heterogeneity of firm evaluations by market participants (the proportion of bond issues in which rating firms disagree in each industry).

The two models in this paper both present limitations and advantages. The first setup has two main advantages. By using market and industry fixed effects it greatly reduces the concern for the presence of additional factors affecting the creation of non-financial firms, improving the precision of the estimation of the differential effect (the coefficient of the interaction term). Indeed, the effect of any variable that does not vary diagonally across the panel (i.e. along both market and industry dimensions) would be incorporated either into the market or into the industry fixed effects. A second advantage is that it reduces the potential concern for simultaneous causality. Banks are likely to be attracted to markets characterized by higher growth rates, implying that higher firm birth rates may be associated with lower market concentration. In a standard regression it would be difficult to disentangle this source of correlation from that induced by the effect of banks' market power on firm dynamics. Our specification largely reduces this problem because it is unlikely that banks would be attracted to a particular market just because one specific industry experienced a relatively higher rate of firm natality. The main drawback of this empirical model is that it can say nothing about the first-order relationship between bank competition and the birth rate of firms.

The second model shares most of the problems and limitation of growth regressions (in particular the need to control for endogeneity), but can provide broad evidence on the total effect of bank competition on firm creation.

We estimate both models employing a panel containing information on 22 industries in 103 Italian local markets, defined as provinces. The Italian data fit the purpose of this study for a number of reasons. First, in Italy bank credit still represents the most important source of funds for the private sector, particularly for new firms, as venture capital remains negligible. Second, local credit markets differ significantly in their banking structure, guaranteeing sufficient cross-sectional variability within a single institutional framework; in addition, the richness of the data is such that 
we can employ a variety of proxies of competition for robustness purposes. Third, information on the stocks and flows for the universe of non-financial firms is available by industry and with a detailed geographic disaggregation, consistent with the definition of local credit markets. Finally, a very large sample of more than 60.000 balance sheet data for non-financial firms is available to compute the opaqueness measure, distinguishing by size and age of the firms.

Although the use of data from a single country may determine a reduction in the generality of results, focusing on local markets within a single country presents three important advantages with respect to cross country studies. First, there is significant evidence that credit markets are subnational, particularly for small or new firms ${ }^{2}$. In this respect, country level indicators of competition may not provide sufficient information on local conditions faced by opaque borrowers. Second, the uniformity of the institutional framework eliminates the need to control for the effects of different regulatory systems and makes it easier to control for changes that may occur over time. Finally, the quality and information content of the data is homogeneous.

Evidence from our first model is consistent with the information-based theories. Indeed, we find a differential effect of bank competition on firm creation that is related to opaqueness. Namely, in less competitive banking markets the rate of birth of firms operating in more opaque industries is relatively higher. In other words, an increase in the degree of bank competition will favor more (or damage less) firms characterized by a lower degree of asymmetric information. This finding does not necessarily imply that competition is detrimental to the creation and development of informationally opaque firms, as nothing is said on the first order effect. The evidence from the economy-wide model in the second part of the paper is consistent with an overall positive effect of bank competition on firm creation, while confirming the differential effect found in the base regression.

The paper is structured as follows. The next section presents a brief summary of the theoretical and empirical literature on the relationship between the structure of the banking industry and the supply of credit; section three introduces the empirical methodology; section four describes the data; section five discusses our findings; and finally, section six concludes.

\section{Theoretical IsSUES AND PREvious EMPIRICAL Literature}

Theory has not yet provided a unambiguous answer to the question of how the degree of competition and the structure of the banking industry affect the availability of credit to new entrepreneurs and, indirectly, the rate of creation of firms. On the one hand, the literature relying on traditional models of industrial organization has stressed the role of bank competition in increasing the supply of credit to borrowers. On the other hand, more recent work has pointed out that, because of asymmetric information, bank competition may be detrimental to the supply of credit when there is imperfect information about potential borrowers.

\footnotetext{
${ }^{2}$ See for example Kwast, Starr-MCluer and Wolken (1997), and Bonaccorsi di Patti and Gobbi (2000).
} 
According to the first view, which abstracts from informational issues, a more competitive banking system should promote the development of new entrepreneurial activities because of lower interest rates and a larger supply of credit to firms. ${ }^{3} \mathrm{~A}$ bank that has some monopoly power faces a downwards sloping demand curve and sets its volume of loans based on the standard conditions of equality between Lerner indices and inverse elasticities (see Freixas and Rochet, 1997). More competition increases the elasticity of the demand for loans faced by each supplier, compressing the mark-up that banks are able to charge to their customers (though not necessarily in a uniform way for all of them).

Conversely, the second view explicitly takes into account information asymmetries and suggests that a more competitive banking system may be detrimental to the development of new firms. According to this view, the relationship between competition in banking and the availability of credit to new firms is likely to be affected by the informational structure of the market. ${ }^{4}$ An increase in the degree of competition may worsen moral hazard ${ }^{5}$ and adverse selection problems ${ }^{6}$ on the borrower side or hold-up problems ${ }^{7}$ on the lender side, leading to higher interest rates and/or a reduced availability of credit to opaque firms. We will refer collectively to all of these effects as to the "informational channel".

The relative importance of these two opposite mechanisms will determine the net effect of competition on credit availability to opaque borrowers and is essentially an empirical issue.

\footnotetext{
${ }^{3}$ Hannan (1991a) presents an application of the standard structure-conduct-performance paradigm to the banking industry. Besanko and Thakor (1992) and Chiappori, Perez-Castrillo, and Verdier (1995) show that in a model of spatial differentiation competition compresses intermediation margins.

${ }^{4}$ In the appendix we present a simple model of banking that provides some useful insights on the interaction between market structure and information.

${ }^{5}$ Hoff and Stiglitz (1997) show that moral hazard problems may drive interest rates up when competition increases. As the number of competitors rises, information flows worsen, weakening reputation effects and borrowers' incentives to repay their debt, and leading to higher interest rates.

${ }^{6}$ An example is Broecker (1990), who analyzes a market for credit where banks compete in a Bertrand fashion over interest rates. He shows that when banks perform independently an imperfect test to screen the credit-worthiness of applicants, the equilibrium loan interest rate can be increasing in the number of banks in the market The intuition behind this result is that the average credit-worthiness of applicant firms that pass the test with at least one bank is decreasing with the number of banks. A similar analysis is in Riordan (1992).

7Petersen and Rajan (1995) show that banks' willingness to lend to new "unknown" firms increases with the banking market concentration, while the interest rate charged decreases. In that "Schumpeterian" perspective, banks would accept to lend to new firms with the prospect to extract some oligopolistic rent from those that result to be successful. Then, a more competitive market reduces the incentive to "invest" in new projects as the ability of extracting future rents is proportional to the bank's market power.
} 
The predictions of conventional theories and information-based theories both find some support in the empirical literature. Hannan (1991b) analyzes the relationship between bank concentration and interest rates on small loans. He finds evidence that commercial loan interest rates tend to be higher in more concentrated banking markets. Black and Strahan (2000) find a strong negative relationship between concentration in the banking industry and the creation of new businesses. Conversely, the findings in Jackson and Thomas (1995) suggest a negative effect of bank size and a positive one of bank concentration on the rate of birth of firms. On the same side, Petersen and Rajan (1995) find that young firms in concentrated banking markets receive more credit than similar firms located in areas with lower concentration indices. Furthermore, they find that such difference tends to disappear as firms get older suggesting that the positive effect of market power diminishes when information asymmetries become less severe. ${ }^{8}$

Indirect evidence of the link between financial structure and the creation of firms is described by Rajan and Zingales (1998). Based on cross-country data, they find that the effect of financial development on growth is mainly due to the increase in the number of productive establishments rather than to the expansion of existing establishments.

In a paper closely related to ours, Cetorelli and Gambera (2000) use the same data as Rajan and Zingales (1998) to study the effects of bank concentration on the rate of growth of different industries. They find that concentration, measured by the country-level market share of the top 3 (or top 5) banks, promotes growth in those industries that are more in need of external financing, and that at the same time it depresses growth overall. Our paper adds to their result by explicitly taking into account asymmetric information as the identifying feature of industries. As discussed in the previous section, there is a trade-off between geographic coverage and the availability of high quality detailed data. The present paper's, focusing on a single country, sacrifices geographic coverage to fully exploit the richness of a dataset that provides detailed information on both banks and borrowers in local markets.

\section{EMPIRICAL METHODOLOGY}

The investigation of the theoretical literature in the previous section suggests that there exists a complex relationship between the structure of the banking industry and the availability of credit to opaque borrowers. The conventional channel is expected to determine a positive effect of competition on the quantity of credit and the informational channel a negative one. Consequently, regressing a measure of credit availability to opaque borrowers on some measure of market power would provide evidence on the total effect but it would say nothing on the existence and empirical relevance of each of the two partial effects. Moreover, to the extent that the relative importance

\footnotetext{
${ }^{8}$ This paper also relates to the small business lending literature. Several authors have studied the static relationship between bank size and propensity to lend to small borrowers. The main findings are that large financial organization tend to have a smaller proportion of their assets in small business loans than small institutions but that small business lending does not decrease in markets affected by mergers and acquisitions. See Berger and Udell, (1998) and Berger, Demsetz and Strahan (1999) for a review of this literature.
} 
of the two effects varied across borrowers in a systematic way, restricting the relationship between competition and credit to non-financial firms to be the same for all firms may introduce a composition bias in the estimation. In what follows, we present two complementary empirical models. The first model emphasizes the industry-specific effect of bank competition, in order to test the empirical relevance of the information channel; the second model is constructed to estimate the economy-wide relationship between bank competition and firm creation.

\section{A. Model I: Industry-Specific Effect}

One implication of information-based theories is that a more competitive banking industry should be disproportionately detrimental to the emergence of new firms in sectors where informational asymmetries play a more substantial role.

In a theoretical model considering a continuum of borrowers with varying degree of opaqueness and a continuum of loan markets with varying degree of competition, the above implication is equivalent to saying that the second cross partial derivative of the availability of credit with respect to market power and opaqueness is positive, at least in a given range of opaqueness (a simple theoretical model that shows this result can be found in the Appendix).

In an econometric model, this second mixed derivative can be estimated as the coefficient of an interaction term constructed as the product of a variable describing the degree of opaqueness and one describing the degree of market power in the banking sector.

A setup to estimate the industry-specific effect of bank competition is:

$$
\begin{aligned}
{\text { Birth } \text { Rate }_{i, j}=} & \text { Constant } \Phi_{1} \cdot \text { Industry dummies } \\
& +\Phi_{2} \cdot \text { Local Market dummies }_{j} \\
& +\varphi_{3} \cdot{\text { Initial industry share of total firms } \text { f }_{i, j}} \\
& +\varphi_{4} \cdot\left(\text { Opaqueness }_{i} \cdot{\text { Bank } \left.\text { Competition }_{j}\right)}\right. \\
& +\varphi_{5} \cdot\left(\text { Size }_{i} \cdot \text { Wealthj }\right) \\
& +\Phi_{6} \cdot \text { Controls }_{i, j} \\
& +\varepsilon_{i, j}
\end{aligned}
$$

Industry and province dummy variables are included to control for industry-specific and market-specific effects, respectively. Consequently, they will absorb the effect of any variable that does not vary simultaneously across industries and local markets.

The initial share of each industry in the local market takes into account the fact that industries that are already very developed at the beginning of the period are unlikely to grow as fast as those that are at an earlier stage of development and that the entry of new firms is less likely to occur in relatively crowded markets. Hence, we expect a negative sign for its coefficient. 
The interaction term is the product of opaqueness in industry $i$ and a proxy for bank competition in market $j$. The "information channel" predicts a negative sign for its coefficient because bank competition is supposed to be relatively more detrimental to firms characterized by a higher degree of asymmetric information.

In order to take into account the fact that entrepreneurs may use personal wealth to start their activities, we add to the regression another interaction term constructed as the product of a proxy of wealth in market $j$ and the value of average fixed cost in industry $i$. We expect a negative sign for this coefficient because personal funds may be a reasonable substitute for bank credit only in industries with a relatively small value of fixed costs. While the direct effect of wealth on the rate of birth of firms should be positive, it should also be relatively less important for industries with very large initial investments in fixed assets.

\section{B. Model II: Economy-Wide Effect}

The previous setup isolates the differential contribution of bank competition to firm creation with respect to varying degrees of opaqueness, the product of $\varphi_{4}$ and the measure of opaqueness, evaluated at different levels of this variable. In our second model we include directly in the regression the proxies for competition in the local market and drop the market fixed effects. Although econometrically less robust, this setup is useful to assess the first order relationship between bank competition and firm creation.

One first problem determined by the absence of the market fixed effects is a larger potential for biases caused by omitted variables that affect the rate of birth of firms in each local market. A second problem is that some of our competition proxies may have a substantial endogenous component with respect to the rate of birth of firms.

Following the existing literature, we address the first problem by including a set of control variables similar to those employed in standard growth regressions, specifically: initial per capita GDP as a convergence variable; a schooling variable as a proxy for human capital; total credit over GDP as a proxy for financial development; and a proxy for the level of infrastructures. ${ }^{9}$ Structural and policy differences not captured by our regressors that may be relevant, particularly in the case of Southern Italy, are controlled for with geographic area dummy variables. ${ }^{10}$ All these variables are described in detail in Section III.F.

We can write Model II as

$$
\begin{aligned}
&{\text { Birth } \text { Rate }_{i, j}=} \text { Constant }+\Psi_{1} \cdot \text { Industry }_{\text {Dummies }} \\
&+\Psi_{2} \cdot \text { Market Controls } \\
&
\end{aligned}
$$

\footnotetext{
${ }^{9}$ See Cetorelli and Gambera (2000) and Black and Strahan (2000).

${ }^{10}$ Italy is divided into 20 administrative regions, each consisting of multiple provinces, for a total of 103. A standard grouping of regions or provinces is that into three geographic areas: Northwest Northeast, Center, South, and Islands (Statictical Bulletin of the Bank of Italy, any year).
} 


$$
\begin{aligned}
& +\psi_{3} \cdot \text { Initial Industry Share of Registered Firms } s_{i, j} \\
& +\psi_{4} \cdot \text { Bank Competition }_{j} \\
& +\psi_{5} \cdot\left(\text { Opaqueness }_{i} \cdot \text { Bank Competition }_{j}\right) \\
& +\psi_{6} \cdot\left(\text { Size }_{i} \cdot \text { Wealthj }\right) \\
& +\Psi_{7} \cdot \text { Controls }_{i, j} \\
& +\varepsilon_{i, j}
\end{aligned}
$$

In the following sections we first motivate our choice of the rate of birth of firms as a proxy for credit availability to informationally opaque borrowers. Then, we illustrate how we measure the degree of opaqueness of the industries and the degree of bank competition in local credit markets.

\section{Measuring Credit Availability}

Three main arguments have motivated our choice of the rate of birth of firms as an indicator of credit availability to entrepreneurs willing to start a business. First, new firms are likely to be affected by the highest level of asymmetric information problems and have no previous history that may mitigate them. Second, information-related problems most likely get reflected in firms not being able to start rather than not being able to get funds to grow once they have already obtained some bank credit. Consequently, the rate of birth of new firms is where the positive effect of market power suggested by the "information channel", if empirically relevant, should be stronger. Finally, data on the birth of firms exist with both local market and industry disaggregation, which is not the case for data on growth.

Another advantage is that we implicitly restrict ex ante our firms to be exogenously opaque in a relatively uniform way, except for industry-specific characteristics that are related to the underlying technology or to the type of business, improving the accuracy of our test. Industry growth rates of value added or other measures of production could be strongly influenced by the behavior of large listed firms - that are less opaque and have access to external financing other than local bank credit - and by the size and age distribution of firms in the industry. ${ }^{11}$

The use of microeconomic data from a sample of existing firms would have allowed us to control for differences in size and age but it would have been intrinsically affected by selection bias since we would have excluded a priori firms never born because too opaque to receive any credit at all.

Empirical support for our strategy is in Rajan and Zingales (1998). In their study the effect of financial development on growth is separated into two components: the effect on the growth of

${ }^{11}$ Admittedly, we cannot control for factors like the reputation of individual entrepreneurs starting new activities. However, unless such components vary both across sectors and provinces, they should be picked up by the fixed effects. 
existing establishments and that on the growth in the number of establishments. The positive effect of financial development on growth is found to be stronger for this second variable, suggesting that financial factors affect primarily the creation of new firms rather than the expansion of existing entities.

\section{Measuring the Degree of Opaqueness}

The literature on financial intermediation measures firm opaqueness with variables that should be correlated to "reputation", typically firm age or size (Petersen and Rajan, 1995), or the length of relationships between the firm and the bank. Alternatively, opaqueness is associated with "bank dependence", often measured as the ratio of bank credit to total debt, either at the industry or at the firm level.

In this paper, since we consider the rate of birth of firms, we cannot use firm age because new firms have all age zero. Size is a proxy for transparency only for existing firms because it is related to the history of the firm, and to auditing and disclosure requirements which tend to become tighter with size. In the context of our study bank dependence cannot be used because it is likely to have a large endogenous component, hence we have excluded any measure based on credit volumes.

In order to measure the degree of opaqueness we refer to two basic types of information asymmetries and their consequences: adverse selection - that emerges when lenders cannot observe the "quality" of individual borrowers - and moral hazard - that emerges when lenders cannot monitor the actions of borrowers. Firms in the same industries are likely to share to some extent a similar degree of these information asymmetries, which will instead vary significantly across industries on the basis of some intrinsic characteristic of the production and organization technology.

Our first assumption is that the type of activity of the "perspective" firm influences the relative importance of adverse selection problems. A bank can evaluate more easily the quality of a business plan or project when they are based on a simple technology, with a large predictable component. For example, making nails or paper from raw materials are activities where the effects of the unobservable quality of human capital or effort are less important in determining the outcome than the provision of professional services.

Our second assumption is that these technological factors affect also moral hazard. Again, lenders' ability to monitor the activities of borrowing firms depends on the technology that characterizes the industry and on the degree of discretion that such technology typically leaves to the manager or entrepreneur. If the technology is complex or there is a large discretionary component, the bank has much to gain from monitoring closely the firm. In addition, some technologies imply naturally the availability of collateral by employing a substantial share of fixed and tangible assets, which reduces moral hazard. ${ }^{12}$

$\overline{{ }^{12} \text { Collateralizable assets can be }}$ contracted upon to reduce moral hazard and adverse selection 
Finally, the severity of hold-up problems is likely to be correlated to the same factors that affect moral hazard. If the activity of the firm is such that monitoring through a relationship has a large value added, the inside bank will be able to extract significant rents from the borrower in the future because of relationship-generated barriers to entry.

Our working assumption is that firm opaqueness varies across industries and is negatively correlated to the relevance of physical capital and other fixed assets in the production process. The larger the share of these assets in the typical balance sheet of firms in the industry the more transparent the industry is. ${ }^{13}$ We have not used intangible assets because they are less homogenous across industries, are often not reported or are equal to zero in some industries. Similarly, we have excluded R\&D expenses because reliable information was not available.

Since firms in different industries may have specific accounting practices and varying degrees of discretion in determining depreciation, we consider the volume of gross physical assets (Table 1). Our indicator of opaqueness is the ratio of gross total assets to gross physical assets (ASYMi $){ }^{14}$ The ratios are computed for 22 industries from individual firm data contained in the Centrale dei Bilanci, a large data set of company balance sheets and income statements, referring to the years $1994-98 .{ }^{15}$

We constructed the industry indicators in the following way. To minimize measurement errors and the effect of outlier, we first dropped companies falling in the 5 percent and 95 percent percentiles of the distribution of our ratios, which restricted the sample to a total of 54,360 firms. We took the average of the annual individual firm ratios observed in the period 1994-1998, in order to remove the effects of temporary shocks to specific companies. Then, we computed the mean of such ratios for each industry. ${ }^{16}$ As discussed below, for robustness we constructed the opaqueness indicator employing only young firms, defined as firms with age less than 5 years (Table 1). ${ }^{17}$

problems (see Freixas and Rochet, 1997). In addition, Myers and Rajan (1998) develop a model where agency problems between owner/manager and creditors are mitigated by the amount of "less liquid" assets, that reduces the uncertainty about risk. Though their argument is presented for the case of a bank, it can be easily extended to non-financial firms.

${ }^{13}$ Support of this view is in the literature on bank opaqueness. Morgan (1999) finds that the disagreement between raters' valuation of banks decreases with the share of premises and fixed assets in the balance sheet.

${ }^{14}$ In a previous version of this paper we employed also the ratio of physical assets net of depreciation to net total assets and our results where unchanged.

${ }^{15}$ Detailed information on Centrale dei Bilanci can be found in Pagano, Panetta, and Zingales (1998). Industries closely related to the availability of natural resources or affected by other special factors were also excluded, because deemed independent from local bank financing (these were the mining and oil industry and transportation).

${ }^{16} \mathrm{We}$ have calculated the opacity measures also as median values rather than means. The estimation of the models yielded similar results. In addition, in a previous version of this paper (Bonaccorsi and Dell'Ariccia, 2000), we obtained similar result using weighted averages. ${ }^{17}$ Alternatively, we have computed the indicator only for small firms, defined as those with total 
An identification problem may emerge when using the described measure of opaqueness in the regression. It could be the case that firms in industries characterized by a high share of physical capital have also high fixed start up costs because they require a lot of physical capital in absolute terms. According to the standard theory, credit supply is generally restricted in less competitive markets. One possible implication is that firms in large need of funds because of large start-up costs will be those that suffer the most as banks for diversification purposes may tend to issue smaller loans in a given number rather than fund a smaller number of large borrowers.

This hypothesis would yield the same prediction of the "information channel" and the interpretation of the coefficient of the interaction term would not be unique. For example, a positive sign of the interaction term between concentration and opaqueness could mean either that more opaque firms are relatively favored where banks have some monopoly power or that firms that have large start up costs are relatively more constrained in these markets. ${ }^{18}$ We resort to two different approaches to distinguish between the two explanations.

The first approach is based on introducing directly a control variable for the initial fixed costs of firms for each industry. This control variable enters the regression interacted with the same measure of bank competition employed to construct the interaction term with the opaqueness measure, purging the second from the potential effect of initial fixed costs. As a proxy of initial fixed costs we employ the average volume of fixed tangible assets of young firms in the industry, defined as those with age less than 5 years $(S I Z E Y i)$.

The second approach attempts to solve this problem by using a proxy for opaqueness that should be more independent from the initial size of the investment in each industry. Morgan (1999) suggests that a measure of the opaqueness of a firm is the extent to which rating agencies disagree on its rating. The same reasoning can be applied at the industry level: a large percentage of firms for which raters disagree (split ratings) reflects a greater difficulty in evaluating firms in that industry, hence greater opaqueness. As described below, we compute for each industry the percentage of firms with split ratings and rank industries by this measure.

The split rating variable (SPLITi) is defined as the percentage of bond issues for each industry where raters disagree; the data refer to about 1200 bond issues between 1983 and 1993 in the US and the industry classification is based on SIC codes. ${ }^{19}$ SIC industry classification

assets less than ITL 5.0 billion (about US $\$ 2.5$ million).

${ }^{18} \mathrm{~A}$ second potential problem was hinted above: some of these indicators may be highly correlated with the availability of collateral. However, even if that were the case, this bias should work against our hypothesis. The reason is that we should expect that firms that are able to provide more collateral are also those that are less rationed, hence they should have a higher rate of birth in concentrated markets, everything else equal. Instead our hypothesis states that firms that are opaque (and have less collateral based on our empirical definition) should have a higher rate of birth in concentrated markets.

${ }^{19}$ The data were collected by the staff in the Capital Market section at the Federal Reserve Board from various public sources, such as Moody's and S\&P manuals, Bond Digest. We are very grateful to Donald Morgan for sharing these data with us. 
can be easily matched with the Italian classification ATECO91, through ISIC classification. In constructing this variable, we first eliminated repetitions from the original data. More specifically, firms with more than one bond issue were counted only once if their rating split did not change across issues; the issues were counted separately if the rating split changed.

Since the rating data that we employ refer to a sample of bond issues in the US, we use the split rating measure as an instrument for our measure based on physical capital. The working assumption remaining that opaqueness is related to technological factors and that the implied industry ranking is persistent across countries. ${ }^{20}$

Table 2 reports the ranking of the industries based on $A S Y M$ and the values of the different opaqueness proxies. A higher rank indicates a greater degree of opaqueness. For example, Construction is a highly opaque industry while Paper and Products, Basic Metal Industries and Wood and Wood Products are all characterized by less information asymmetries. The ranking is quite consitent across proxies and, as expected, young firms tend to be more opaque than the average firm in each industry.

\section{E. Measuring Bank Competition}

The next task is to select a suitable measure of the degree of competitiveness in the banking industry at the local market level. Most empirical studies have employed structural measures, typically the Herfindahl index or other concentration ratios. ${ }^{21}$ The ability of these structural measures to capture the degree of competition in a market depends crucially on the particular form of strategic interaction that actually takes place. ${ }^{22}$ Because we do not have information on this aspect, we employ six alternative measures.

First, given its widespread use in policy and empirical analysis, we use the Herfindahl index calculated on deposits market shares.

Second, under the assumption that significant changes in the market structure of the industry affect banks' expectation to extract future rents from borrowers, ${ }^{23}$ we construct two measures of structural change in the banking sector: the absolute variation of the Herfindahl index between 1996 and 1998 and the sum of the absolute variation of the market shares of individual banks. ${ }^{24}$

\footnotetext{
${ }^{20}$ See Rajan and Zingales (1998) for a similar approach.

${ }^{21}$ See for a recent example, Cetorelli and Gambera (1999).

${ }^{22}$ For example, in a Salop model of competition on the circle, to a more competitive market (lower transportation costs) corresponds a lower number of firms, and thus a larger Herfindahl index. ${ }^{23}$ Information-based theories predict that not only present market power but also banks' expectation to extract rents in the future influences the supply of credit to opaque borrowers (a model in that spirit is in Petersen and Rajan, 1995).

${ }^{24}$ Structural measures are criticized because they are static. Although these measures are not strictly dynamic, they are correlated to how much market shares are reshuffled among banks, partially answering to this criticism.
} 
An important aspect of competitiveness that may not be captured by the measures described above is potential competition. Unfortunately, reliable data on interest rate margins are not available, particularly because it is difficult to control for the risk component embedded in the observed spreads. We then resort to measures of entry.

We consider the market share of banks that were originally chartered within the local market as proxy of the degree of closure with respect to entry by outside banks in neighboring markets. This measure is likely to be related also to the importance of soft information possibly precluded to banks originating in different markets. ${ }^{25}$

As a direct measure of entry, we calculate the share of branches opened in each province in year $t$ by banks that were not present in that province in year $t-1$. Finally, we employ a measure that includes entry inclusive of the effects of mergers and acquisitions. These measures may be affected by more endogeneity problems than structural measures of competitiveness because banks are likely to enter markets where there is higher growth and, possibly, a higher rate of birth of firms. While this problem is mitigated in Model I, it is likely to be serious in the average industry model. Hence, we do not estimate Model II with entry-based variables.

\section{F. Data and Variables Description}

To implement our test we employ a panel of data referring to 22 industries and 103 Italian local credit markets, defined as provinces, in the period 1996-1999. ${ }^{26}$ Yearly observations are averaged over time so each observation for our dependent variable is the annualized rate of birth of firms in industry $i$ and province $j$ in the entire period.

The source of data on the number of firms in each industry and province is the database Movimprese, published by InfoCamere. Movimprese contains aggregate information collected from local firm registries, including the number of firms that register in each year by province, type of legal entity, and by activity based on a detailed classification. End of year stocks of registered firms, of operating firms, and the number of firms that get cancelled are available as well. The information collected by Infocamere has undergone significant changes over time and homogeneous data is available only since 1996.

Three variables have been computed for non-financial firms. The dependent variable in our regressions (BIRTHij) is the average annual rate of birth of firms in industry $i$ and province $j$ over the years $1997-99$, where for each year $t$ such rate is defined as the ratio of newly registered

${ }^{25}$ Hannan (1991) finds empirical evidence in support of the thesis that bank commercial loan markets are local in nature. Kwast, Starr-McCluer, and Wolken (1997) discuss market definition issues for antitrust in banking and find that in the US local banks are by far the dominant providers of key assets and credit services to small businesses. They define local institutions as institutions located within 30 miles of the headquarters office of the small business.

${ }^{26}$ Data on banks are based on end of year statistics for the period 1996-98 while the rate of birth of firms are based on annual flows for the period 1997-99 normalized by end of previous year stocks. 
firms in each province in year $t$ divided by the number of total registered firms at the end of year $t-1$. An important advantage of our data is the availability of information on gross flows. We compute the actual rate of birth of firms rather than deriving it from beginning and end of period stocks, which would include the potential effect of exogenous factors on the "death" of firms. ${ }^{27}$

Second, as in standard growth regressions, we control for the relative size of each sector since there could be a convergence effect such that industries with fewer firms at the beginning of the sample period have relatively higher birth rates and because new entry is more likely to occur in less "crowded" markets; we include the variable REGSHAREij defined as the number of registered firms in industry $i$ and province $j$ divided by the total number of registered firms in province $j$ at the end of year 1996.

In some of the specifications, we include as a control variable the number of firms that have been cancelled from the registry ( $D E A T H i j$ ), defined as the yearly average of the annual ratio of canceled firms in year $t$ divided by total registered firms at the end of year $t-1$. Our concern was that new firms replaced dead ones in markets where there was a high turnover due to exogenous factors varying both across markets and industries (whose effects would not be captured by the industry or the province fixed effects). In addition, we wanted to control for the fact that firms that change name would be counted as one firm cancelled and one new firm.

The measures of the degree of competition in the local banking sector are constructed from the statistics on commercial banks collected by the Bank of Italy. The Herfindahl index ( $H E R F j$ ) is the average of the yearly sum of the squares of the market shares of deposits in province $j$, based on the location of the branch. The variable $L O C B A N K S j$ is the share of deposits in province $j$ held by banks chartered in province $j$, again as the average of yearly observations. The absolute variation of Herfindahl ( $A B S V H E R F j$ ) in the period considered is the sum of the absolute values of the yearly changes in the index. The index of mobility of market shares ( $M O B S H A R E S j$ ) is the sum of the absolute values of the changes in individual bank deposit market shares between year $t$ and year $t-1$. Yearly values have been averaged over the period considered. The variable ENTRY $j$ is the sum over $t=1996,1997,1998$ of branches in year $t$ that belong to banks that were not present in that market in year $t-1$ divided by the number of branches in the province in 1996. Finally, (ENTRYM\&Aj) is the same variable not corrected for entry due to mergers and acquisitions. Table 3 reports the descriptive statistics for the panel.

In all the specifications we have included the interaction term between a proxy of wealth in the province and a measure of average size of young firms in the industry, to control for personal

\footnotetext{
${ }^{27}$ One important caveat in the definitions of Movimprese is that firms may be "not active", that is they may be under liquidation or bankruptcy procedure, but not yet canceled from the registry. Conversely, firms that are registered and inactive may become active without implying any change in the number of registered firms. We have observed that there are significant differences in the ratio of active to registered firms across regions, suggesting both differences in bureaucracy efficiency and differences due to the sectorial composition of firms. As a robustness check, we have employed birth rates calculated with respect to active fims rather than registered ones and no significant difference was found in the results.
} 
wealth as an alternative to bank credit to fund a new activity. The proxy for wealth is per capita nominal value added in 1996, the initial year of our sample ( $W E A L T H j$ ). Size is measured by the variable $S I Z E Y i$, computed as the average of the volume of physical capital of young firms in the industry (with age less than five years), with the same procedure described for $A S Y M j$ and $A S Y M Y j$.

In some of the specifications we have included the interaction between a proxy of start up costs and competition measures for the reasons discussed in section 3.4. For this purpose we have employed the variable $S I Z E Y i$ defined as the average volume of physical capital for firms with age less than five years in the Centrale dei Bilanci sample in each industry $i$.

For the purpose of the estimation of Model II, we have computed several control variables that enter the regression in place of the province fixed effects. As a proxy for human capital we employ the percentage of the population with a high school degree or a college degree ( $H C A P I T A L j$ ) obtained from Italian Census data. The variable $B A N K D E V j$ is a standard proxy for development of the banking system, calculated as the ratio of total credit to GDP in 1996 , the initial year of the period examined. The variable $R O A D S j$, a proxy for the level of infrastructures, is the number of kilometers of roads per 100 squared $\mathrm{km}$ in the region the province belongs to. A set of standard geographical dummy variables, based on the classification of the Bank of Italy statistics, control for structural differences bewteen areas of the country. These variables are $N E A S T j, C E N T E R j, S O U T H j$ and $I S L A N D j$ and are equal to 1 if the province is part of the North East, Center, South of Italy or if it is in Sicily or Sardinia, respectively, 0 otherwise (North West is the excluded category).

\section{RESULTS}

\section{A. The Industry-Specific Effect}

In the base regression $B I R T H i j$ is a function of industry and market fixed effects, and of the interaction term between $A S Y M i$ and bank competition in market $j$. We employed alternatively each of the measures of competition. Control variables that are included in the basic specification are the proportion of firms in the industry $i$ and in market $j$ in 1996 (SHAREij) and the interaction between per capita GDP in 1996 and the average size of fixed assets of firms in industry $i$, to control for personal wealth as an alternative source of funds for start-ups ( $W E A L T H j * S I Z E Y i$ ). Coefficients for the industry and province fixed effects are not shown.

This basic regression (Table 4-A) shows that all the interaction term coefficients have the expected sign and that five out of six are statistically significant. ${ }^{28}$ The coefficient of the

\footnotetext{
${ }^{28}$ The coefficient of the interacted term based on the Herfindhal index is not significant. One possible explanation for this result is that, arguably. the Herfindhal index is not an effective measure of competition for the banking industry (see note 22)
} 
proportion of registered firms also has the expected negative sign and is statistically significant. The coefficient for the second interaction term has the expected negative sign but is not significant.

For robustness we repeated the exercise using $A S Y M Y j$, the opaqueness measure computed only for young firms (Table 4-B). The estimates of the interaction terms for these robustness checks support the conclusions of our base regression. ${ }^{29}$

For all three specifications and all interaction terms, we also tested for the relevance of the potential effect of the "administrative turnover" of firms, by introducing the rate of cancellation of firms $(D E A T H i j)$. We find that this variable is significant and has a positive coefficient (see Tables 5-A and 5-B) indicating that higher rates of creation of firms tend to be correlated to higher rates of exit from the industry in local markets. Results from these further robustness check confirmed our previous findings since the coefficients of the interaction term maintained their expected sign, with a slight loss in significance. Further analysis is required since the cancellation rate may be partly endogenous if banks in less competitive markets encourage the birth of lower quality firms that will have a greater mortality. ${ }^{30}$

A third set of estimates addresses the issue of a potential identification problem related to our measure of firm opaquenss. As discussed previously, firms with a larger share of fixed assets might have also large fixed start up costs. If, as from standard theories, credit supply is restricted in less competitive markets, these same firms would be the ones to suffer the most from the lack of competition. The interaction term would have the same sign as that predicted by the "information channel", but for a different reason.

The first robustness check we have performed to rule out this explanation is to include in the regressions an interaction term between the same competition measure in each specification, and the inverse of the volume of fixed assets of young firms in each industry. We employed the inverse of the variable $S I Z E Y i$ because this way the sign of the coefficient predicted by the start-up costs hypothesis should be the same as that of the interaction term between $A S Y M i$ and the competition measure.

Results of the estimation with this control variable show that the main interaction term retains its sign and significance (Table 6). The interaction term between competition and the inverse of $S I Z E Y i$ has instead the opposite sign, suggesting that competition in the banking sector is relatively more beneficial for firms that have small start-up costs, holding constant other characteristics of the industry.

As a second approach, we instrumented the measure $A S Y M i$ with the variable SPLITi. As described in section III.D, the variable SPLITi represents the percentage of firms with split ratings in industry $i$, from a sample of rating data of US firms. This particular specification

\footnotetext{
${ }^{29}$ We have also employed the measure based only on firms with total assets less than ITL 5.0 billion. Results were consistent but less siginficant.

${ }^{30}$ The short time-length of our sample partly mitigates this endogeneity problem, since cancelled firms were most likely registered before the beginning of our time frame.
} 
of our empirical model was estimated under the assumption that there is some technological reason behind opaqueness and that the industry ranking implied by such technological difference persists across countries. However, the only statistical condition required for this specification is correlation between the variable SPLITi and ASYMi, and independence of SPLIT $i$ from the start-up cost in industry $i$.

Results for the instrumental variables estimation are reported in Table 7 . In the estimation we have instrumented directly the interaction term with an interaction term constructed multiplying the split rating variable with each proxy of competition. Again, the results from this specification are consistent with our main findings, with four interacted terms coefficients out of six with expected sign and significant.

A final robustness check was performed, by including simultaneously multiple measures of competition in the regression. Our concern was that static and dynamic measures captured different aspects of how the structure of the banking industry is related to competition. In particular, the static market power measures such as $H E R F j$ and $L O C B A N K S j$ do not take adequately into account factors like contestability or rivalry. On the other hand, measures of structural change alone do not take into account initial conditions. We tried to supply to this problem by estimating the model including more than one competition measure in the same specification. The results reported in Table 8 broadly confirm our previous findings. In addition, the inclusion of static and dynamic measures of competition tends to increase the significance of the static measures without significantly changing their coefficients.

In summary, the empirical evidence in this section is consistent with the idea that a higher degree of competition in the banking industry is more detrimental (or less favorable) to firms operating under more severe asymmetric information conditions.

However, until now we have not taken any view with regard to the total effect of competition on firm creation. We present some evidence in the next section.

\section{B. The Economy-Wide Effect}

In Model II the potential for an endogeneity problem of entry-based competition measures with respect to the rate of birth of firms is virtually unsolvable. Indeed, we expect that measures closely related to entry are significantly influenced by the dynamics of economic activity in the local market, hence by the rate of birth of firms. It is reasonable, instead, that structural measures whose cross-sectional dispersion varies more slowly over time should be less affected although not entirely immune. Thus, we have estimated the economy-wide effect only for the proxies that are more closely related to structural factors, specifically $H E R F, A B S V H E R F$ and $L O C B A N K S j .{ }^{31}$ In addition, the robustness tests reported in Table 8 have suggested to employ jointly concentration and the change in concentration since there are no longer the fixed

\footnotetext{
${ }^{31}$ Results were unchanged if we employed in the regression initial values for the structural proxies instead of three-year period means.
} 
effects and it is reasonable that the two variables capture different relevant features of the banking industry. We will briefly discuss the results for various specifications that include $H E R F$ and $A B S V H E R F$ (Table 9). Similar results were obtained with the variable $L O C B A N K S$ but will not be discussed for the sake of brevity.

In all the specifications reported concentration enters the regression with a linear and a second order term, both having significant coefficients. The linear term has a positive coefficient while the squared terms has a negative coefficient, indicating an inverted U-shape average relationship between $H E R F$ and $B I R T H$. This parabola reaches its maximum around a value of $H E R F$ of 23 per cent in the basic specification (column 1). On average, very low values of concentration are associated to low firm birth rates, but high concentration is detrimental to the creation of firms. In other words, some competition is good, too much may be a problem.

This finding is consistent with the results of other studies. Cetorelli and Gambera (2001) find a relationship of a similar shape between growth and concentration in the banking industry. Jackson and Thomas (1995) find a positive effect of bank concentration on employment growth in new firms and a negative effect for mature firms, consistent with the view that the effect of concentration is not homogeneous across firms with different opaqueness.

We have then estimated the total effect of concentration allowing for differences based on opaqueness, by including the interaction term between $A S Y M$ and $H E R F$. These estimates confirm the signs and significance of the interaction term (Table 8, column 2, 4 and 5) and are robust to the inclusion of the cancellation rate and the start-up costs variable. SImilarly, $A B S V H E R F$ and its interaction terms are robust.

Taking the estimated parameters of column 6 we can evaluate the effect of concentration on the rate of birth of firms for different industries based on the most complete specification (Figure 1). This derivative is a function of the values of $H E R F$ and $A S Y M$ if we set $S I Z E Y$ at its mean value. For example, for firms with a relatively low opaqueness ( 25 th percentile), the derivative is equal to 0.44 at the mean value of $H E R F$ (18.2 per cent). It turns negative when $H E R F$ is larger than 19.1 per cent). If we consider a relatively high level of opaqueness (75th percentile), the derivative of $B I R T H$ with respect to $H E R F$ is equal to 1.6 at the mean value of $H E R F$, and turns negative when $H E R F$ is around 21.7 per cent. When opacity is equal to the maximum value observed in our sample of industries, the derivative remains positive for values of $H E R F$ below 32 per cent.

The purpose of this simple exercise is to show that $H E R F$ has a relatively larger effect for more opaque industries on $B I R T H$ when the derivative is positive, and a negative effect smaller in absolute value for these same industries. The differential effect is represented by the vertical shift between the lines depicted in Figure 1. Clearly, the derivative itself is positive for relatively low values of concentration and turns negative for high values, suggesting that high concentration is detrimental to the creation of firms. In addition, Figure 1 is suggestive of a dominance of the economy-wide effect of bank competition over its differential effect depending on opaqueness, as the second is relatively small in magnitude. 
The estimation of Model II confirms the other findings concerning the effect of WEALTH and start-up costs. In local markets with a higher per capita GDP firms with smaller start-up costs are relatively favored, suggesting that personal wealth is a substitute for banks credit. Finally, we find evidence in the data of a sort of convergence effect on the creation of firms, since provinces with relatively more registered firms and more infrastructures have lower rates of birth. The general level of bank development is not significant but has a positive sign. Human capital, instead, appears to be negatively correlated with the creation of firms perhaps because of lower opportunity costs of high level education in environmnets with less business opportunities.

\section{Conclusions}

In this paper we addressed the issue of the empirical relevance of those theories that argue that a positive relationship between bank market power and the availability of credit to opaque borrowers exists. We focused on the empirical relationship between bank competition and the rate of birth of non-financial firms with different degrees of asymmetric information. The evidence we found in a panel of Italian data at the province level is consistent with the view that competition is relatively more beneficial to the rate of birth of firms in industries characterized by a lower degree of opaqueness. The results appear to be robust to alternative measures of opaqueness and different proxies of competition. The analysis in this paper provides also some evidence on a non-linear economy-wide relationship between banking competition and firm creation: very low values of concentration are associated to low firm birth rates, on average, but high concentration is detrimental to the creation of firms. Finally, in a range of relatively low market power and for very opaque industries, there is also evidence of a dominance of the "information-based" negative effect of competition over standard positive effects. 
Table 1. Indicators of Asymmetric Information

\begin{tabular}{llccc}
\multicolumn{1}{c}{ Definition } & Name & Mean & $75^{\circ}$ perc. & $25^{\circ}$ perc. \\
\hline Gross total assets/Gross physical assets & ASYM & 13.678 & 14.522 & 5.940 \\
$\begin{array}{llll}\text { Gross total assets/Gross physical assets for firms } \\
\text { less than 5 year old }\end{array}$ & ASYMY & 18.233 & 22.001 & 9.975 \\
$\begin{array}{l}\text { Percentage of split ratings } \\
\text { SPLIT }\end{array}$ & 55.7 & 59.2 & 53.1 \\
\hline
\end{tabular}


Table 2. Industry Ranking and Opaqueness Measures

\begin{tabular}{lccc}
\hline \multicolumn{1}{c}{ Industry } & ASYM & ASYMY & SPLIT \\
\hline Construction & 53.29 & 67.50 & 64.3 \\
Wholesale Trade & 34.74 & 41.04 & 57.4 \\
Vehicie Trade and Repair & 22.82 & 27.82 & 46.1 \\
Apparel and Finished Textile Products & 18.27 & 22.00 & 69.2 \\
Printing, Publishing and Allied Industries & 17.46 & 23.03 & 55.8 \\
Professional Equipment & 15.59 & 19.42 & 60.0 \\
Retail Trade and Repair Services & 14.52 & 16.14 & 63.7 \\
Leather and Leather Products & 14.37 & 18.08 &. \\
Non-electrical Machinery and Office Equipment* & 13.24 & 18.37 & 57.5 \\
Electrical and Electronic Machinery and Supplies & 12.76 & 16.98 & 59.0 \\
Textiles & 11.39 & 23.35 & 54.5 \\
Automobiles, Other Vehicles and Parts & 8.96 & 15.19 & 61.1 \\
Chemicals, Fibers and Allied Products & 8.81 & 12.18 & 54.3 \\
Furniture, Toys and Miscellaneous Manufacturing & 8.78 & 12.18 & 53.1 \\
Metal Products & 6.95 & 8.22 & 53.3 \\
Hotels, Restaurants and Bars & 6.36 & 10.35 & 58.1 \\
Food and Beverages & 5.94 & 9.97 & 51.8 \\
Basic Metal Industries & 5.72 & 10.94 & 52.2 \\
Wood and Wood Products & 5.66 & 7.33 & 33.3 \\
Rubber and Miscellaneous Plastic Products & 5.18 & 6.61 & 51.3 \\
Stone, Clay, Glass and Concrete Products & 5.10 & 7.43 & 55.5 \\
Paper and Allied Products & 4.91 & 6.90 & 59.2 \\
\hline
\end{tabular}

Note: a higher position in the ranking indicates greater opaqueness. Source: Centrale dei Bilanci (199498). The table reports the ranking obtained ordering industries by descending values for the indicators listed. *We have grouped Computers and Office Equipment with Non-electrical Machinery to obtain consistency with the US classification and because rates of birth in the first industry had extreme values due to the very small number of firms. 
Table 3. Variable Definition and Descriptive Statistics

Observations are stacked as in the estimation and are averages over time of the original data for the period 1996-1998 except where specified. The number of observations is 2266 (22 industries and 103 provinces).

\begin{tabular}{|c|c|c|c|c|c|}
\hline \multicolumn{2}{|l|}{ Variable } & Mean & S. Dev. & Min & Max \\
\hline BIRTH & Percentage Rate of Birth of Firms & 5.604 & 2.660 & 0 & 32.326 \\
\hline REGSHARE & Share of Total Registered Firms & 0.031 & 0.051 & 0 & 0.310 \\
\hline DEATH & Percentage Rate of Cancellation of Firms & 5.749 & 2.090 & 0 & 19.978 \\
\hline HERF & $\begin{array}{l}\text { Herfindahl Index of Deposits by location of } \\
\text { branches }\end{array}$ & 0.182 & 0.080 & 0.053 & 0.538 \\
\hline LOCBANKS & $\begin{array}{l}\text { Share of Deposits held by Local Chartered } \\
\text { Banks }\end{array}$ & 0.404 & 0.230 & 0 & 0.939 \\
\hline ABSVHERF & $\begin{array}{l}\text { Absolute Change of Herfindahl between } 1996 \\
\text { and } 1998\end{array}$ & 0.020 & 0.022 & 0.0003 & 0.134 \\
\hline MOBSHARES & $\begin{array}{l}\text { Sum of absolute values of annual changes in } \\
\text { market shares, yearly average }\end{array}$ & 0.077 & 0.028 & 0.031 & 0.175 \\
\hline ENTRY & $\begin{array}{l}\text { Number of branches of banks not present in the } \\
\text { market in year } t-1 \text { divided by the total number } \\
\text { of branches in year } t \text {, cumulated }\end{array}$ & 0.058 & 0.092 & 0 & 0.516 \\
\hline $\begin{array}{l}\text { ENTRYM\& } \\
\text { A }\end{array}$ & $\begin{array}{l}\text { As ENTRY but includes banks that enter by } \\
\text { acquisition or mierger }\end{array}$ & 0.076 & 0.101 & 0 & 0.516 \\
\hline WEALTH & Per capita Value Added in 1996 , million ITL & 29.098 & 7.889 & 15.707 & 48.056 \\
\hline SIZEY & $\begin{array}{l}\text { Average industry value of fixed assets for firms } \\
\text { with less than } 5 \text { years (billion ITL) }\end{array}$ & 2.127 & 2.274 & 0.277 & 11.473 \\
\hline HCAPITAL & $\begin{array}{l}\text { Share of population with high school or college } \\
\text { degree }\end{array}$ & 21.266 & 3.128 & 14.40 & 33.20 \\
\hline BANKDEV & Ratio of Bank Credit to Value Added in 1996 & 0.551 & 0.159 & 0.214 & 1.572 \\
\hline ROADS & $\begin{array}{l}\text { Kilometers of roads divided by the area of the } \\
\text { province (square Kilometers } / 100 \text { ) }\end{array}$ & 108.36 & 25.800 & 51.799 & 159.0 \\
\hline NEAST & $\begin{array}{l}\text { Equal to } 1 \text { if the province is in the North East, } 0 \\
\text { otherwise }\end{array}$ & 0.213 & 0.409 & 0 & 1 \\
\hline NWEST & $\begin{array}{l}\text { Equal to } 1 \text { if the province is in the North West, } \\
0 \text { otherwise }\end{array}$ & 0.233 & 0.422 & 0 & 1 \\
\hline CENTER & $\begin{array}{l}\text { Equal to } 1 \text { if the province is in the Center, } 0 \\
\text { otherwise }\end{array}$ & 0.155 & 0.362 & 0 & 1 \\
\hline SOUTH & $\begin{array}{l}\text { Equal to } 1 \text { if the province is in the South, } 0 \\
\text { otherwise }\end{array}$ & 0.223 & 0.416 & 0 & 1 \\
\hline ISLAND & $\begin{array}{l}\text { Equal to } 1 \text { if the province is in Sicily or } \\
\text { Sardinia, } 0 \text { otherwise }\end{array}$ & 0.126 & 0.332 & 0 & 1 \\
\hline
\end{tabular}


Table 4-A. Bank Competition and Firm Birth Rate (ASYM)

The dependent variable is the ratio between the number of newly registered firms and the number of registered firms at the end of the preceding period. Annual data for the period 1997-1999 are averaged over time. HERF, LOCBANKS and MOBSHARES are averages of annual data. ABSVHERF is the sum of absolute values of yearly changes. ENTRY and ENTRYM\&A are the ratio of branches opened by outside banks in the period divided by end of 1996 number of branches. ASYM is the inverse of gross physical assets divided by gross total assets and is the industry average for the period 1994-1998. REGSHARE is the industry's share of the total number of registered firms is computed dividing the 1996 number of registered firms of the industry by the total number of registered firms in that year in each local market in 1996. The coefficients for the constant terms and industry and market indicator variables are not reported. Robust standard errors are below coefficients.

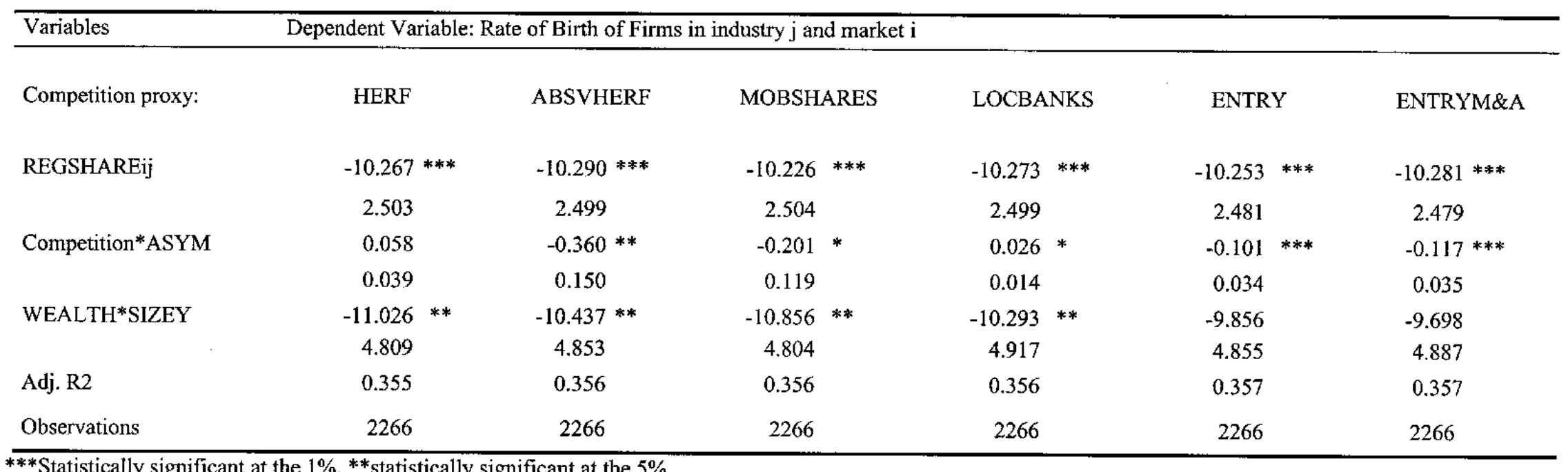

*** Statistically significant at the $1 \%, * *$ statistically significant at the $5 \%$. 
Table 4-B. Bank Competition and Firm Birth Rate (ASYM for young firms)

The dependent variable is the ratio between the number of newly registered firms and the number of registered firms at the end of the preceding period. Annual data for the period 1997-1999 are averaged over time. HERF, LOCBANKS and MOBSHARES are averages of annual data. ABSVHERF is the sum of absolute values of ycarly changes. ENTRY and ENTRYM\&A are the ratio of branches opened by outside banks in the period divided by end of 1996 number of branches. ASYMY is the inverse of gross physical assets divided by gross total assets and is the industry average for the period 1994-1998 for young firms. REGSHARE is the industry's share of the total number of registered firms is computed dividing the 1996 number of registered firms of the industry by the total number of registered firms in that year in each local market in 1996. The coefficients for the constant terms and industry and market indicator variables are not reported. Robust standard errors are below coefficients.

\begin{tabular}{|c|c|c|c|c|c|c|c|c|c|c|c|}
\hline \multirow{2}{*}{$\begin{array}{l}\text { Variables } \\
\text { Competition proxy: }\end{array}$} & \multicolumn{11}{|c|}{ Dependent Variable: Rate of Birth of Firms in industry $\mathrm{j}$ and market $\mathrm{i}$} \\
\hline & \multicolumn{2}{|c|}{ HERF } & \multicolumn{2}{|c|}{ ABSVHERF } & \multicolumn{2}{|c|}{ MOBSHARES } & \multicolumn{2}{|c|}{ LOCBANKS } & \multicolumn{2}{|c|}{ ENTRY } & \multirow{2}{*}{$\begin{array}{l}\text { ENTRYM\&A } \\
-10.337 * * *\end{array}$} \\
\hline REGSHARE & -10.292 & $* * *$ & -10.337 & $* * *$ & -10.263 & $* * *$ & -10.313 & $* * *$ & -10.375 & $* * *$ & \\
\hline & 2.504 & & 2.497 & & 2.507 & & 2.497 & & 2.485 & & 2.486 \\
\hline \multirow[t]{2}{*}{ Competition*ASYMY } & 0.053 & & -0.254 & $* *$ & -0.177 & $*$ & 0.019 & $*$ & -0.083 & $* * *$ & $-0.075 * * *$ \\
\hline & 0.032 & & 0.122 & & 0.096 & & 0.011 & & 0.029 & & 0.027 \\
\hline \multirow[t]{2}{*}{ WEALTH*SIZEY } & -11.020 & ** & -10.571 & $* *$ & -10.862 & ** & -10.438 & $* *$ & -10.028 & ** & $-10.103^{* *}$ \\
\hline & 4.808 & & 4.841 & & 4.805 & & 4.889 & & 4.868 & & 4.847 \\
\hline Adj. R2 & 0.355 & & 0.356 & & 0.356 & & 0.356 & & 0.357 & & 0.356 \\
\hline Observations & 2266 & & 2266 & & 2266 & & 2266 & & 2266 & & 2266 \\
\hline
\end{tabular}

*** Statistically significant at the $1 \%, * *$ statistically significant at the $5 \%$. 
Table 5-A. Bank Competition and Firm Birth Rate (ASYM, controlling for DEATH)

The dependent variable is the ratio between the number of newly registered firms and the number of registered firms at the end of the preceding period. Annual data for the period 1997-1999 are averaged over time. HERF, LOCBANKS and MOBSHARES are averages of annual data. ABSVHERF is the sum of absolute values of yearly changes. ENTRY and ENTRYM\&A are the ratio of branches opened by outside banks in the period divided by end of 1996 number of branches. ASYM is the inverse of gross physical assets divided by gross total assets and is the industry average for the period 1994-1998. REGSHARE is the industry's share of the total number of registered firms is computed dividing the 1996 number of registered firms of the industry by the total number of registered firms in that year in each local market in 1996. The coefficients for the constant terms and industry and market indicator variables are not reported. Robust standard errors are below coefficients. The basic regression is reported below. DEATH is given by the ratio between the number of firms canceled and the number of registered firms at the end of the preceding year. Annual data for the period 1997-1999 are averaged over time. The coefficients for the constant terms and industry and market indicator variables are not reported. Robust standard errors are below coefficients

\begin{tabular}{|c|c|c|c|c|c|c|}
\hline Variables & Dependent Variabl & of Birth of Fin & dustry $\mathrm{j}$ and mark & & & \\
\hline Competition proxy: & HERF & ABSVHERF & MOBSHARES & LOCBANKS & ENTRY & ENTRYM\&A \\
\hline \multirow[t]{2}{*}{ REGSHARE } & $-9.014 * * *$ & $-9.039^{* * *}$ & $-8.977 * * *$ & $-9.022 * * *$ & $-9.037 * * *$ & $-9.007 * * *$ \\
\hline & 2.436 & 2.432 & 2.436 & 2.429 & 2.414 & 2.413 \\
\hline \multirow[t]{2}{*}{ Compctition*ASYM } & 0.041 & $-0.303 * *$ & $-0.185^{*}$ & $0.032 * *$ & $-0.112 * * *$ & $-0.100^{* * *}$ \\
\hline & 0.036 & 0.141 & 0.109 & 0.0134 & 0.032 & 0.031 \\
\hline \multirow[t]{2}{*}{ WEALTH*SIZEY } & -3.913 & -3.464 & -3.782 & -3.113 & -2.755 & -2.861 \\
\hline & 2.616 & 2.644 & 2.616 & 2.676 & 2.656 & 2.643 \\
\hline \multirow[t]{2}{*}{ DEATH } & $0.375 * * *$ & $0.374 * * *$ & $0.375^{* * * *}$ & $0.376^{* * *}$ & $0.373^{* * *}$ & $0.374 * * *$ \\
\hline & 0.053 & 0.053 & 0.053 & 0.053 & 0.053 & 0.053 \\
\hline Adj. R2 & 0.409 & 0.409 & 0.409 & 0.410 & 0.410 & 0.410 \\
\hline Observations & 2266 & 2266 & 2266 & 2266 & 2266 & 2266 \\
\hline
\end{tabular}

*** Statistically significant at the $1 \%,{ }^{* *}$ statistically significant at the $5 \%$. 
Table 5-B. Bank Competition and Firm Birth Rate (ASYM for young firms, controlling for DEATH)

The dependent variable is the ratio between the number of newly registered firms and the number of registered firms at the end of the preceding period. Annual data for the period 1997-1999 are averaged over time. HERF, LOCBANKS and MOBSHARES are averages of annual data. ABSVHERF is the sum of absolute values of yearly changes. ENTRY and ENTRYM\&A are the ratio of branches opened by outside banks in the period divided by end of 1996 number of branches. ASYM is the inverse of gross physical assets divided by gross total assets and is the industry average for the period 1994-1998 for young firms. REGSHARE is the industry's share of the total number of registered firms is computed dividing the 1996 number of registered firms of the industry by the total number of registered firms in that year in each local market in 1996. The coefficients for the constant terms and industry and market indicator variables are not reported. Robust standard errors are below coefficients. The basic regression is reported below. DEATH is given by the ratio between the number of firms canceled and the number of registered firms at the end of the preceding year. Annual data for the period 1997-1999 are averaged over time. The coefficients for the constant terms and industry and market indicator variables are not reported. Robust standard errors are below coefficients

\begin{tabular}{|c|c|c|c|c|c|c|c|c|c|c|c|}
\hline \multirow{2}{*}{ Variables } & \multicolumn{11}{|c|}{ Dependent Variable: Rate of Birth of Firms in industry $\mathrm{j}$ and market $\mathrm{i}$} \\
\hline & \multicolumn{2}{|c|}{ HERF } & \multicolumn{2}{|c|}{ ABSVHERF } & \multicolumn{2}{|c|}{ MOBSHARES } & \multicolumn{2}{|c|}{ LOCBANKS } & \multicolumn{2}{|c|}{ ENTRY } & ENTRYM\&A \\
\hline \multirow[t]{2}{*}{ REGSHARE } & -8.698 & $* * *$ & -8.728 & $* * *$ & -8.673 & $* * *$ & -8.724 & $* * *$ & -8.744 & $* * *$ & $-8.776 * * *$ \\
\hline & 2.484 & & 2.479 & & 2.486 & & 2.476 & & 2.468 & & 2.468 \\
\hline \multirow[t]{2}{*}{ Competition*ASYMY } & 0.042 & & -0.176 & & -0.161 & * & 0.020 & * & -0.070 & $* * *$ & $-0.074 * * *$ \\
\hline & 0.029 & & 0.114 & & 0.086 & & 0.011 & & 0.025 & & 0.026 \\
\hline \multirow[t]{2}{*}{ WEALTH*SIZEY } & -10.934 & $* *$ & -10.615 & $* *$ & -10.797 & $* *$ & -10.337 & $* *$ & -10.084 & $* *$ & $-10.054 * *$ \\
\hline & 4.761 & & 4.784 & & 4.755 & & 4.839 & & 4.807 & & 4.820 \\
\hline \multirow[t]{2}{*}{ DEATH } & 0.375 & $* * *$ & 0.374 & $* * *$ & 0.375 & $* * *$ & 0.375 & $* * *$ & 0.375 & $* * *$ & $0.374 * * *$ \\
\hline & 0.052 & & 0.052 & & 0.052 & & 0.052 & & 0.052 & & 0.053 \\
\hline Adj. R2 & 0.4132 & & 0.413 & & 0.413 & & 0.413 & & 0.414 & & 0.414 \\
\hline Observations & 2266 & & 2266 & & 2266 & & 2266 & & 2266 & & 2266 \\
\hline
\end{tabular}

***Statistically significant at the $1 \%,{ }^{* *}$ statistically significant at the $5 \%$, *statistically significant at the $10 \%$ level. 
Table 6. Bank Competition and Firm Birth Rate (ASYM, controlling for start-up costs)

The dependent variable is the ratio between the number of newly registered firms and the number of registered firms at the end of the preceding period. Annual data for the period 1997-1999 are averaged over time. HERF, LOCBANKS and MOBSHARES are averages of annual data. ABSVHERF is the sum of absolute values of yearly changes. ENTRY and ENTRYM\&A are the ratio of branches opened by outside banks in the period divided by end of 1996 number of branches. ASYM is the inverse of gross physical assets divided by gross total assets and is the industry average for the period 1994-1998 for young firms. REGSHARE is the industry's share of the total number of registered firms is computed dividing the 1996 number of registered firms of the industry by the total number of registered firms in that year in each local market in 1996. The coefficients for the constant terms and industry and market indicator variables are not reported. Robust standard errors are below coefficients. The basic regression is reported below. DEATH is given by the ratio between the number of finns canceled and the number of registered firms at the end of the preceding year. Annual data for the period 1997-1999 are averaged over time. The cocfficients for the constant terms and industry and market indicator variables are not reported. Robust standard errors are below coefficients

\begin{tabular}{|c|c|c|c|c|c|c|c|c|c|c|c|}
\hline \multirow{2}{*}{$\begin{array}{l}\text { Variables } \\
\text { Competition proxy: }\end{array}$} & \multicolumn{11}{|c|}{ Dependent Variable: Rate of Birth of Firms in industry $j$ and market $i$} \\
\hline & \multicolumn{2}{|c|}{ HERF } & \multicolumn{2}{|c|}{ ABSVHERF } & \multicolumn{2}{|c|}{ MOBSHARES } & \multicolumn{2}{|c|}{ LOCBANKS } & \multicolumn{2}{|c|}{ ENTRY } & \multirow{2}{*}{$\begin{array}{l}\text { ENTRYM\&A } \\
-10.557 * * *\end{array}$} \\
\hline REGSHARE & -10.317 & $* * *$ & -10.513 & $* * *$ & -10.447 & $* * *$ & -10.322 & $* * *$ & -10.388 & $* * *$ & \\
\hline & 2.508 & & 2.481 & & 2.489 & & 2.494 & & 2.476 & & 2.473 \\
\hline \multirow[t]{2}{*}{ Competition*ASYM } & 0.074 & * & -0.631 & $* * *$ & -0.480 & $* * *$ & 0.042 & $* * *$ & -0.184 & $* * *$ & $-0.202 * * *$ \\
\hline & 0.043 & & 0.157 & & 0.143 & & 0.016 & & 0.038 & & 0.039 \\
\hline \multirow[t]{2}{*}{ WEALTH*SIZEY } & -10.999 & $* *$ & -10.916 & ** & -11.014 & $* *$ & -10.838 & $* *$ & -11.031 & $* *$ & $-10.889 * *$ \\
\hline & 4.817 & & 4.869 & & 4.815 & & 5.002 & & 4.848 & & 4.910 \\
\hline \multirow[t]{2}{*}{ Competition*(1/SIZEY) } & -0.339 & & 6.037 & $* * *$ & 6.150 & $* * *$ & -0.377 & * & 1.885 & $* * *$ & $1.947 * * *$ \\
\hline & 0.554 & & 2.258 & & 1.886 & & 0.208 & & 0.574 & & 0.652 \\
\hline Adj. R2 & 0.355 & & 0.357 & & 0.357 & & 0.356 & & 0.359 & & 0.359 \\
\hline Observations & 2266 & & 2266 & & 2266 & & 2266 & & 2266 & & 2266 \\
\hline
\end{tabular}

*** Statistically significant at the $1 \%, * *$ statistically significant at the $5 \%$. 
Table 7. Bank Competition and Firm Birth Rate (ASYM, Instrumental Variables Estimation)

The dependent variable is the ratio between the number of newly registered firms and the number of registered firms at the end of the preceding period. Annual data for the period 1997-1999 are averaged over time. HERF, LOCBANKS and MOBSHARES are averages of annual data. ABSVHERF is the sum of absolute values of yearly changes. ENTRY and ENTRYM\&A are the ratio of branches opened by outside banks in the period divided by end of 1996 number of branches. ASYM is the inverse of gross physical assets divided by gross total assets and is the industry average for the period 1994-1998. REGSHARE is the industry's share of the total number of registered firms is computed dividing the 1996 number of registered firms of the industry by the total number of registered firms in that year in each local market in 1996. Competition*ASYM is instrumented with Competition*SPLIT. The coefficients for the constant terms and industry and market indicator variables are not reported.

Robust standard errors are below coefficients.

\begin{tabular}{|c|c|c|c|c|c|c|c|c|c|c|c|}
\hline \multirow{2}{*}{ Variables } & \multicolumn{11}{|c|}{ Dependent Variable: Rate of Birth of Firms in industry $j$ and market $i$} \\
\hline & \multicolumn{2}{|c|}{ HERF } & \multicolumn{2}{|c|}{ ABSVHERF } & \multicolumn{2}{|c|}{ MOBSHARES } & \multicolumn{2}{|c|}{ LOCBANKS } & \multicolumn{2}{|c|}{ ENTRY } & ENTRYM\&A \\
\hline \multirow[t]{2}{*}{ SHARE } & -11.353 & $* * *$ & -11.195 & $* * *$ & -11.337 & $* * *$ & -11.299 & $* * *$ & -11.128 & $* * *$ & $-11.091 * * *$ \\
\hline & 2.476 & & 2.513 & & 2.495 & & 2.492 & & 2.505 & & 2.507 \\
\hline \multirow[t]{2}{*}{ Competition*ASYM } & -0.031 & & -1.008 & $* *$ & -0.885 & $* *$ & 0.019 & & -0.187 & $*$ & $-0.219 *$ \\
\hline & 0.104 & & 0.392 & & 0.357 & & 0.035 & & 0.109 & & 0.120 \\
\hline \multirow[t]{2}{*}{ WEALTH*SIZEY } & -11.524 & $* *$ & -11.435 & $* *$ & -11.497 & $* *$ & -11.496 & $* *$ & -11.397 & $* *$ & $-11.378^{* *}$ \\
\hline & 4.898 & & 4.903 & & 4.888 & & 4.898 & & 4.896 & & 4.902 \\
\hline Adj. R2 & 0.352 & & 0.353 & & 0.353 & & 0.352 & & 0.353 & & 0.353 \\
\hline Observations & 2163 & & 2163 & & 2163 & & 2163 & & 2163 & & 2163 \\
\hline
\end{tabular}

***Statistically significant at the $1 \%, * *$ statistically significant at the $5 \%$. 
Table 8. Bank Competition and Firm Birth Rate: Robustness with All Indicators

The coefficients for the constant terms and industry and market indicator variables are not reported. Robust standard crrors are below coefficients

\begin{tabular}{|c|c|c|c|c|c|c|c|c|c|c|c|}
\hline Variables & Denendent & Varia & IRTH & & & & & & & & \\
\hline \multirow[t]{2}{*}{ REGSHARE } & -10.317 & $* * *$ & -10.774 & $* * *$ & -10.315 & *** & -8.728 & $* * *$ & -10.829 & $* * *$ & $-9.179 * * *$ \\
\hline & 2.499 & & 2.480 & & 2.481 & & 2.462 & & 2.461 & & 2.450 \\
\hline \multirow[t]{2}{*}{ HERF*ASYM } & 0.113 & $* * *$ & 0.166 & $* * *$ & 0.100 & $* *$ & 0.073 & * & 0.142 & $* * *$ & $0.114^{* * *}$ \\
\hline & 0.041 & & 0.455 & & 0.039 & & 0.037 & & 0.043 & & 0.041 \\
\hline \multirow[t]{2}{*}{ ABSVHERF*ASYM } & -0.518 & $* * *$ & -0.862 & $* * *$ & -0.463 & *** & -0.340 & $* *$ & -0.746 & $* * *$ & $-0.552 * * *$ \\
\hline & 0.153 & & 0.167 & & 0.155 & & 0.148 & & 0.156 & & 0.146 \\
\hline \multirow[t]{2}{*}{ ENTRY*ASYM } & - & & & & -0.078 & $* *$ & -0.067 & $* *$ & -0.146 & $* * *$ & $-0.138 * * *$ \\
\hline & - & & & & 0.035 & & 0.031 & & 0.039 & & 0.036 \\
\hline \multirow[t]{2}{*}{ LOCBANKS*ASYM } & - & & & & 0.018 & & 0.020 & & 0.026 & * & $0.024 *$ \\
\hline & - & & & & 0.014 & & 0.013 & & 0.015 & & 0.013 \\
\hline \multirow[t]{2}{*}{ WEALTH*SIZEY } & -10.356 & ** & -10.870 & ** & -9.106 & $*$ & -9.250 & * & -10.890 & $* *$ & $-10.813 * *$ \\
\hline & 4.846 & & 4.865 & & 4.972 & & 4.920 & & 5.063 & & 5.014 \\
\hline \multirow[t]{2}{*}{$\operatorname{HERF}^{*}(1 / \mathrm{SIZEY})$} & - & & -1.163 & * & - & & 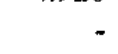 & & -0.911 & & -0.890 \\
\hline & - & & 0.600 & & - & & - & & 0.591 & & 0.569 \\
\hline \multirow[t]{2}{*}{ ABSVHERF*(1/SIZEY) } & - & & 7.654 & $* * *$ & - & & - & & 6.435 & $* * *$ & $4.836 * *$ \\
\hline & - & & 2.485 & & - & & - & & 2.395 & & 2.247 \\
\hline \multirow[t]{2}{*}{ ENTRY*(1/SIZEY) } & - & & - & & - & & - & & 1.579 & $* * *$ & $1.618 * * *$ \\
\hline & - & & - & & - & & - & & 0.584 & & 0.548 \\
\hline \multirow[t]{2}{*}{ LOCBANKS*(1/SIZEY) } & - & & - & & - & & - & & -0.214 & & 0.137 \\
\hline & - & & - & & - & & - & & 0.209 & & 0.199 \\
\hline \multirow[t]{2}{*}{ DEATH } & - & & - & & - & & 0.371 & $* * *$ & - & & $0.370 * * *$ \\
\hline & - & & - & & - & & 0.0523 & & - & & 0.052 \\
\hline Adj. R2 & 0.357 & & 0.358 & & 0.358 & & 0.414 & & 0.360 & & 0.416 \\
\hline Observations & 2266 & & 2266 & & 2266 & & 2266 & & 2266 & & 2266 \\
\hline
\end{tabular}

***Statistically significant at the $1 \%, * *$ statistically significant at the $5 \%$. 
Table 9. Bank Competition and Firm Birth Rate: Total Effect

The coefficients for the constant and the industry fixed effects are not reported. Robust standard errors arc below coefficients.

\begin{tabular}{|c|c|c|c|c|c|c|}
\hline \multirow{3}{*}{$\begin{array}{l}\text { Variables } \\
\text { REGSHARE }\end{array}$} & & & \multicolumn{4}{|c|}{ Dependent Variable: BIRTH } \\
\hline & $-8.690 * * *$ & $-8.706 * * *$ & -6.491 & $* * *$ & $-6.517 * * *$ & $-6.900 * * *$ \\
\hline & 1.948 & 1.948 & 2.001 & & 1.998 & 1.996 \\
\hline \multirow[t]{2}{*}{ HERF } & $13.504 * * *$ & $11.942 * * *$ & 11.491 & $* * *$ & $10.354 * * *$ & $10.715 * * *$ \\
\hline & 2.294 & 2.445 & 2.214 & & 2.358 & 2.416 \\
\hline \multirow[t]{2}{*}{ HERF SQUARED } & $-28.534 * * *$ & $-28.535 * * *$ & -23.298 & $* * *$ & $-23.331 * * *$ & $-23.357 * * *$ \\
\hline & 4.425 & 4.451 & 4.322 & & 4.338 & 4.341 \\
\hline \multirow[t]{2}{*}{ ABSVHERF } & $-11.354^{* * *}$ & -4.148 & -9.377 & $* * *$ & -4.136 & -6.126 \\
\hline & 3.034 & 4.532 & 2.866 & & 4.280 & 4.551 \\
\hline \multirow[t]{2}{*}{ HERF*ASYM } & - & $0.114 * * *$ & - & & $0.084 * *$ & $0.135 * * *$ \\
\hline & - & 0.042 & - & & 0.039 & 0.044 \\
\hline \multirow[t]{2}{*}{ ABSVHERF $*$ ASYM } & - & $-0.526 * * *$ & - & & $-0.384 * *$ & $-0.668 * * *$ \\
\hline & - & 0.178 & - & & 0.169 & 0.203 \\
\hline \multirow[t]{2}{*}{ WEALTH*SIZEY } & $-10.494 * *$ & -9.957 & -10.840 & $* *$ & $-10.447 * *$ & $-10.816 * *$ \\
\hline & 4.868 & 4.906 & 4.822 & & 4.858 & 4.886 \\
\hline \multirow[t]{2}{*}{ BANKDEV } & -0.102 & -0.102 & 0.565 & & 0.561 & 0.558 \\
\hline & 0.391 & 0.390 & 0.378 & & 0.377 & 0.377 \\
\hline \multirow[t]{2}{*}{ WEALTH } & -0.218 & -0.229 & -0.169 & & -0.178 & -0.171 \\
\hline & 0.167 & 0.167 & 0.154 & & 0.154 & 0.154 \\
\hline \multirow[t]{2}{*}{ ROADS } & -0.003 & -0.003 & -0.004 & $* *$ & $-0.004 * *$ & $-0.004 * *$ \\
\hline & 0.002 & 0.002 & 0.002 & & 0.002 & 0.002 \\
\hline \multirow[t]{2}{*}{ HCAPITAL } & $-0.043 * *$ & $-0.043 * *$ & -0.052 & $* * *$ & $-0.052 * * *$ & $-0.052 * * *$ \\
\hline & 0.020 & 0.020 & 0.019 & & 0.019 & 0.019 \\
\hline \multirow[t]{2}{*}{ NORTHEAST } & $0.364 * *$ & $0.364 * *$ & 0.314 & $* *$ & $0.314 * *$ & $0.314 * *$ \\
\hline & 0.143 & 0.143 & 0.136 & & 0.136 & 0.136 \\
\hline \multirow[t]{2}{*}{ CENTER } & 0.155 & 0.155 & 0.121 & & 0.121 & 0.122 \\
\hline & 0.164 & 0.164 & 0.150 & & 0.150 & 0.150 \\
\hline \multirow[t]{2}{*}{ SOUTH } & $0.533^{* *}$ & $0.533 * *$ & 0.546 & $* *$ & $0.546^{* * *}$ & $0.546 * * *$ \\
\hline & 0.210 & 0.210 & 0.192 & & 0.192 & 0.192 \\
\hline \multirow[t]{2}{*}{ ISLANDS } & -0.149 & -0.149 & -0.152 & & -0.152 & -0.151 \\
\hline & 0.269 & 0.269 & 0.253 & & 0.253 & 0.253 \\
\hline \multirow[t]{2}{*}{ DEATH } & - & - & 0.405 & $* * *$ & $0.403 * * *$ & $0.401 * * *$ \\
\hline & - & - & 0.055 & & 0.055 & 0.055 \\
\hline \multirow[t]{2}{*}{$\operatorname{HERF}^{*}(1 / \mathrm{SIZEY})$} & - & - & - & & - & $-2.764 *$ \\
\hline & - & - & - & & - & 0.626 \\
\hline \multirow[t]{2}{*}{$\operatorname{ABSVHERF}^{*}(1 / \mathrm{SIZEY})$} & - & - & - & & - & $6.305 * *$ \\
\hline & - & - & - & & - & 2.579 \\
\hline Adj. R2 & 0.242 & 0.245 & 0.318 & & 0.319 & 0.320 \\
\hline Observations & 2222 & 2222 & 2222 & & 2222 & 2222 \\
\hline
\end{tabular}


Figure 1: Derivative of BIRTH with respect to HERF, as a function of HERF (evaluated for 25th, 50 th and 75 th percentile of ASYM)

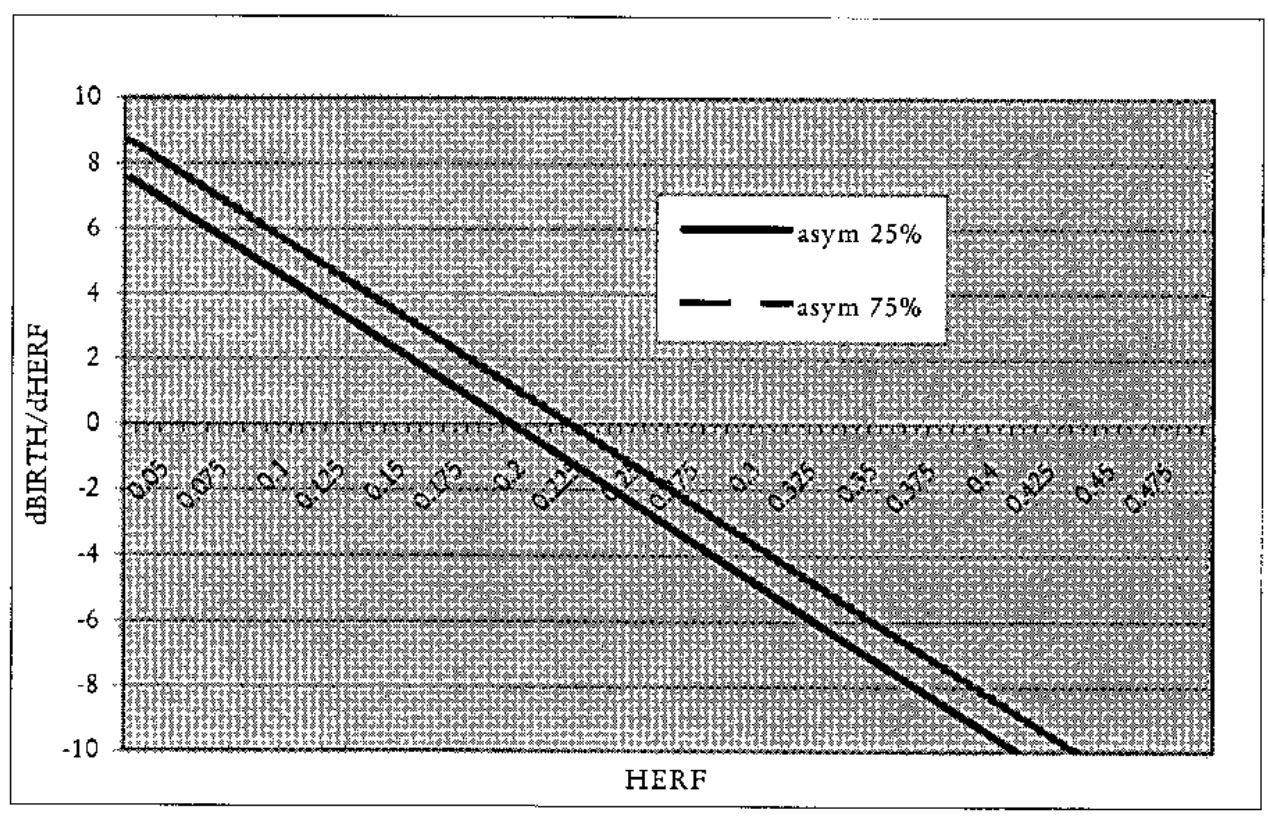




\section{A Simple Model}

In this appendix, we present a simple model of a loan market that emphasizes the interaction between competition and information in banking. This model is not meant to be realistic, general, or particularly original. Its main purpose is provide some intuition for the results of our empirical investigation. This model deals with problems of "ex-post competition". Other models, focusing on adverse selection, rather than hold-up problems, would deliver the result form am ex-ante point of view.

This model describes a hold up problem similar to that in Petersen and Rajan (1995). However, in this model banks' market power is, in part, endogenously determined by the information structure. For simplicity the model concentrates on the negative effects of bank competition on credit availability and disregards the positive effects. It would be easy to modify the model to include traditional positive effects.

Consider a market where there are $N$ identical banks seeking projects in which to invest their capital, and a continuum of entrepreneurs seeking banks to finance their investment projects. Projects may succeed and pay a return $y$ or fail and pay 0 . Entrepreneurs are heterogeneous in their credit-worthiness. Namely, there are "good" and "bad" entrepreneurs, with relative weights $q$ and $1-q$. The former succeed and pay back the debt with probability $\theta_{h}$, and latter with probability $\theta_{l}<\theta_{h}$. We assume that the market is viable: $\bar{\theta} y-1>0$, and that "bad" entrepreneurs are expected not to repay the loan: $\theta_{l} y-1<0$

The model articulates on two periods. In period one, entrepreneurs are born. Their type is unknown and only their type distribution is public information. Banks compete over interest rates and entrepreneurs are financed.

At the beginning of period two, banks learn the creditworthiness of their clients by virtue of the lending relationship they established in period one. In addition, banks have access to a costless, but "imperfect", screening technology that enables them to evaluate the credit-worthiness of each other's clients. This technology consists of a test that with probability $p$ delivers an informative signal and with probability $1-p$ delivers an uninformative signal. For simplicity, we assume that adverse selection problems are bad enough that banks abstain from bidding for firm on which they do not obtain positive information.

In what follows we will refer to the "incumbent" or the "inside" bank as the bank that has lent to a particular borrower in period one, and so has learned that borrower's type.

In what follows, we assume that test results are public information, so that whenever at least one banks obtains an informative result from its test, each bank is informed of it. Then, the incumbent bank remains a monopolist when no bank obtain a positive result from the test. Alternatively, all banks compete for a borrower over the interest rate when at least one bank obtains a positive outcome from the test on that borrower. 
The period-two expected profit for the incumbent (the bank who lent to that particular firm in period one) can be written as the weighted sum of competition and monopoly profits, that results in

$$
\Pi_{i}=\left(\theta r_{m}-1\right)(1-p)^{n-1}
$$

in other words, the incumbent's period-two expected profit is the monopolist's profit weighted by the probability that no bank obtains positive information about the incumbent's client.

It is easy to show that the incumbent's period-two expected profit is decreasing in $p$ and in $n$. The accuracy of the test is an inverse measure of asymmetric information. To one extreme, $p=0$, the incumbent enjoys full informational monopoly on its borrowers. To the other extreme, $p=1$, the incumbent has no informational advantage over other banks. Then, as $p$ increases, the expected informational rents that accrue to the incumbent diminish. Similarly, when $n$ increases, the probability that at least one bank is able to compete for the incumbent's clients increases, and the expected profit for the incumbent diminishes.

Primarily, we are interested in the interaction between these two effects; that is in how asymmetric information affects the relationship between the number of banks in the market and the incumbent's profits. Formally, we are interested in the derivative of the difference $\Pi_{2, i}(n-1)-\Pi_{2, i}(n)$ with respect to $p$. We can write

$$
\Delta \Pi_{2}(n)=\Pi_{2, i}(n-1)-\Pi_{2, i}(n)=\left(\theta r_{m}-1\right)(1-p)^{n-1} p
$$

and after some calculations we can state

$$
\frac{\partial \Delta \Pi_{2}(n)}{\partial p}<0 \Leftrightarrow p>\frac{1}{n-1} .
$$

This result points to a non-monotonic impact of asymmetric information on the relationship between incumbent profits and the number of banks in the market. The intuition for this result is straightforward. The effect of one additional competing bank is zero for perfectly transparent sectors $(p=1)$, where Bertrand competition always prevail, and for perfectly opaque sectors $(p=0)$ where the inside bank always retains its monopoly power. Then, it is at intermediate levels of opaqueness that changes in the degree of competition have the maximum effect on the inside bank profits. The result of our empirical investigation support such a shape for the relationship. However, that evidence also suggests that the ascending side of the curve is economically irrelevant as it pertains to levels of opaqueness at which credit is likely not to exist at all.

Now consider period one. In period one, all banks have the same information about new firms and compete over the interest rate in a Bertrand fashion. Borrowers can result good or bad with probability $q$ and $1-q$. Good borrowers repay debt with probability $\theta$. Bad borrowers are unable to repay the loan.

As in most Bertrand games, we can solve this model by imposing a zero profit condition. In this case, we have to keep into account the expected period-two profits stemming from the 
informational advantage that each bank obtains vis a vis its clients. Then, we can write

$$
\Pi_{1}(n)+\delta E\left[\Pi_{2}(n)\right]=0
$$

(where $\delta$ is the discount factor) that gives an equilibrium gross interest rate

$$
\widehat{r}(n, p)=\frac{1-\delta\left(\theta r_{m}-1\right)(1-p)^{n-1}}{\theta q}
$$

with

$$
\Delta \widehat{r}(n, p)=\widehat{r}(n, p)-\widehat{r}(n-1, p)>0
$$

and

$$
\frac{\partial \Delta \widehat{r}(n, p)}{\partial p}<0 \Leftrightarrow p>\frac{1}{n-1}
$$

The jump from this overly simplified theoretical model to our empirical estimation only needs one more step consisting of a function describing the rate of birth of new firms as a decreasing function of the loan equilibrium interest rate. Let us define the rate of birth of new entrepreneurial firms as

$$
b=f(\widehat{r}, X)
$$

where $X$ is a vector of variables affecting $b$, and $\frac{\partial f}{\partial r}<0$. Then, abstracting from the fact that $n$ is in the natural domain, we can write

$$
\frac{\partial b}{\partial n}=\frac{\partial f}{\partial \widehat{r}} \frac{\partial \widehat{r}}{\partial n}<0
$$

and

$$
\frac{\partial^{2} b}{\partial n \partial p}=\frac{\partial f}{\partial \widehat{r}} \frac{\partial^{2} \widehat{r}}{\partial n \partial p}>0 \Leftrightarrow p>\frac{1}{n-1}
$$

that is negative for low values of $p$ and positive for high values of $p$. 


\section{REFERENCES}

Besanko, D., and A. Thakor, 1992, "Banking Deregulation: Allocational consequences of relaxing entry barriers", Journal of Banking and Finance, Vol. 16, pp. 909-932.

Berger, A., Demsetz R., and P. Strahan, 1999, "The Consolidation of the Financial Services Industry: Causes, Consequences, and Implications for the Future," Journal of Banking and Finance 23, 2-4: 135-194.

Berger, A., and G. Udell, 1998, "The Economics of Small Business Finance: The Role of Private and Debt Markets in the Financial Growth Cycle," Journal of Banking and Finance 22 (6-8): 613-673.

Black, S. and P. Strahan, 2000, "Entrepreneurship and Bank Credit Availability", Federal Reserve Bank of New York, mimeo.

Centrale dei Bilanci, 1997, Economia e finanza delle imprese italiane: decimo rapporto 1982-1995, Bancaria Editrice, Rome.

Cetorelli, N., and M. Gambera, 1999, "Banking Market Structure, Financial Dependence and Growth: International Evidence from Industry Data", Federal Reserve Bank of Chicago Working Paper.

Chiappori, P.A., Perez-Castrillo, D., and T. Verdier, 1995, "Spatial Competition in the Banking System: Localization, cross-subsidies and the regulation of deposit rates", European Economic Review, Vol. 39, pp. 889-918.

Dell'Ariccia, G., Friedman, E., and R. Marquez, 1999, "Adverse Selection as a Barrier to Entry in the Banking Industry", RAND Journal of Economics, Vol. 30, Autumn, pp.515-534.

Freixas, X., and J. Rochet, Microeconomics of Banking, MIT Press 1997.

Hannan, T., 1991a, "Foundations of the Structure-Conduct-Performance Paradigm in Banking", Journal of Money, Credit and Banking, Vol. 23, pp. 68-84. , 1991b, "Bank Commercial Loan Markets and the Role of Market Structure: Evidence from Surveys of Commercial Lending" Journal of Banking and Finance 15, February: 133-149.

Hoff, K., and J. Stiglitz, 1997, "Moneylenders, and bankers: price-increasing subsidies in a monopolistically competitive market," Journal of Development Economics, pp.429-462.

Jackson, J., and A. Thomas, 1995, "Bank Structure and New Business Creation Lessons from an Earlier Time", Regional Science and Urban Economics, Vol. 25, pp. 323-353.

Kwast M., M. Starr-McCluer, and J. Wolken, 1997, "Market Definition and th Analysis of Antitrust in Banking", The Antitrust Bulletin, Winter.

Levine, R., 1997, "Financial Development and Economic Growth: Views and Agenda", Journal of Economic Literature, Vol. XXXV, June, 688-726. 
Morgan, D., 1999, “Judging the Risk of Banks: Why Can't Bond Raters Agree?”, Federal Reserve Bank o New York Working Paper.

Myers, S., and R. Rajan, 1998, "The Paradox of Liquidity", Quarterly Journal of Economics, CXIII, August: 733-773.

Pagano, M., Panetta F., and L. Zingales, 1998, "Why Do Companies Go Public? An Empirical Analysis", Journal of Finance 53.

Petersen, M., and R. Rajan, 1995, "The Effect of Credit Market Competition on Lending Relationships", Quarterly Journal of Economics 110 (May): 407-443.

Petersen M., and R. Rajan, 1994, "The Benefits of Firm-Creditor Relationships: Evidence from Small Business Data", Journal of Finance, 49 March, pp.3-37.

Rajan, R. and L. Zingales,1998, "Financial Dependence and Growth," American Economic Review, Vol. 88, pp.559-586.

Riordan, M., 1993, "Competition and Bank Performance: a Theoretical Perspective", in C. Mayer and X. Vives, editors, Capital Markets and Financial Intermediation, Cambridge University Press.

Sharpe S.A., 1990, "Asymmetric Information, Bank Lending and Implicit Contracts: A Stylized Model of Customer Relationships", Journal of Finance, 45, September, pp.1069-87.

Storey, D.J., 1994, "New Firm Growth and Bank Financing", Small Business Economics, Vol. 6, pp.139-150. 